\section{PENGARUH UKURAN PERUSAHAAN, SOLVABILITAS, DAN PROFITABILITAS TERHADAP AUDIT DELAY \\ Studi Empiris Pada Perusahaan Sektor Perbankan Yang Terdaftar Di Bursa Efek Indonesia}

\author{
Magfira Alawiah dan David HM Hasibuan \\ Program Studi Akuntansi, Sekolah Tinggi Ilmu Ekonomi Kesatuan \\ Bogor, Indonesia \\ Email :lemlit@stiekesatuan.ac.id
}

\section{ABSTRACT}

Timeliness in financial reporting is an obligation for companies listed on the Indonesia Stock Exchange to submit periodic financial report. Delay in financial reporting will have a negative effect on a company, because it may indicate the existence of financial problem within the company. The length of time of an audit conducted by an auditor can be seen from the time different between the financial statment date and the date the auditor's report was signed in the financial statement. The time different is often called an audit delay. The longer the auditor completes the audit, the longer the audit delay is. If the audit delay is long, the delay in submitting financial statment to stakeholders will be longer. Prompt financial reporting is essential to maintain the accuracy of information presented in the financial statement.

The purpose of this study is to identify and explain the influence of Firm Size, Solvability, and Profitability to Audit Delay. The population used is Banking Company listed on Indonesia stock Exchange during the period 2015-1017. The variables used in this research are Firm Size, Solvability, and Profitability. The data used is the company's financial statements are published through the website www.idx.co.id. Data colletion method used is purposive sampling method. Analysis of the data in this study using classic assumption test, multiple linear regressioin analysis and hypothesis testing.

Based on the research that has been done can be the concluded that the partial factor Firm Size significant effect on Audit Delay while the Solvability and Profitability has no significant effect on Audit Delay. Simultaneously factor Firm Size, Solvability and Profitability effect on audit Delay the R Square value is 0.242 indicates that $24,2 \%$ of Audit Delay cab be explained by the independent variables used in the study, while the remaining $75,8 \%$ is explained by other variables.

Keywords: Audit Delay, Firm Size, Solvability, and Profitability.

\section{PENDAHULUAN}

Laporan keuangan merupakan hasil dari proses akuntansi, yang membantu para pengguna laporan keuangan untuk mengetahui kondisi keuangan suatu entitas sehingga dapat memudahkan para pembuat keputusan dalam mengambil keputusan ekonomi.

Menurut pernyataan Standar Akuntansi Keuangan (PSAK) no.1 (IAI,2017), tujuan dari laporan keuangan adalah memberikan informasi terkait dengan posisi keuangan, kinerja keuangan, dan arus kas entitas sehingga membantu para pengguna laporan keuangan dalam pengambilan keputusan. Laporan keuangan merupakan bentuk pertanggungjawaban manajemen terhadap penggunaan sumber daya dalam mendukung aktivitas perusahaan. Laporan keuangan menyajikan informasi yang terkait dengan : (a) aset; (b) liabilitas; (c) ekuitas; (d) penghasilan dan beban, termasuk keuntungan dan
Pengaruh

Ukuran

Perusahaan,

Solvabilitas, dan

Profitabilitas

terhadap Audit

Delay (Study

empiris pada

perusahaan

perbankan yang

terdaftar di

Bursa Efek

Indonesia)

318

Submitted:

MEI 2019

Accepted:

OKTOBER 2019

\footnotetext{
JIAKES

Jurnal Ilmiah Akuntansi Vol. 7 No 2, 2019 pg. $318-330$ IBI Kesatuan Kesatuan ISSN $2337-7852$
} 
Pengaruh

Ukuran

Perusahaan, Solvabilitas, dan Profitabilitas terhadap Audit Delay(Study empiris pada perusahaan perbankan yang terdaftar di Bursa Efek Indonesia)

kerugian; (e) kontribusi dari dan distribusi kepada pemilik dalam kapasitasnya sebagai pemilik; dan (f) arus kas.

Informasi yang tersedia dalam laporan keuangan, sangat membantu para pengguna laporan keuangan dalam memprediksi arus kas masa depan entitas terhadap kepastian diperolehnya arus kas masa depan.

Bagi perusahaan yang sudah go public memiliki kewajiban menyampaikan laporan keuangan, sesuai dengan Standar Akuntansi Keuangan dan telah di audit oleh akuntan public yang terdaftar pada Otoritas Jasa Keuangan (OJK).

Dalam Pernyataan Standar akuntansi Keuangan (PSAK: 2017) tentang Kerangka Dasar Penyusunan dan Penyajian Laporan Keuangan, dikatakan bahwa laporan keuangan harus memenuhi empat karakteristik kualitatif yaitu : dapat dipahami, relevan, memiliki keandalan, dan dapat dibandingkan.

Laporan keuangan harus dilaporkan tepat waktu, karena keterlambatan pelaporan, dapat menimbulkan reaksi negatif dari para pelaku pasar modal. Keterlambatan penyampaian laporan keuangan, dapat menimbulkan berkurangnya kepercayaan stakeholders, tentu hal ini akan mempengaruhi harga jual saham dan menyulitkan stakeholders dalam membuat keputusan maupun prediksi. Keterlambatan penyampaian laporan keuangan, umumnya dianggap sebagai pertanda buruk bagi kondisi kesehatan keuangan perusahaan.

Keterlambatan dalam penyampaian laporan keuangan yang telah diaudit mengindikasikan adanya audit delay pada perusahaan. Audit delay sendiri merupakan jarak waktu antara tanggal laporan keuangan sampai tanggal saat auditor mengeluarkan laporan audit. Semakin lama auditor menyelesaikan laporan audit maka audit delay semakin panjang. Bagi perusahaan yang terlambat dalam menyampaikan laporan keuangannya akan dikenakan sanksi administrasi dan denda sesuai dengan ketentuan yang telah ditetapkan oleh udang-undang. Untuk mengatasi masalah tersebut maka OJK dalam undang-undang nomor 29/POJK.04/2016 mengenai laporan tahunan emiten atau perusahaan publik dalam pasalnya yang ke 7 point 1 mengatakan bahwa "emiten atau perusahaan publik wajib menyampaikan laporan tahunan kepada OJK, selambatlambatnya pada akhir bulan keempat setelah tahun buku berakhir". Bagi perusahaan yang melanggar ketentuan tersebut akan dikenakan sanksi sesuai pasal 19 point 1 dimana sanksi yang diberlakukan adalah: (1) peringatan tertulis, (2) denda (3) pembatasan kegiatan usaha, (4) pembekuan kegiatan usaha, (5) pencabutan izin usaha, (6) pembatalan persetujuan dan, (7) pembatalan pendaftaran.

Penelitian yang terkait dengan audit delay telah banyak diteliti, namun penelitian ini berbeda dengan penelitian yang telah ada. Adapun faktor-faktor yang mempengaruhi terjadinya audit delay antara lain : ukuran perusahaan, solvabilitas dan profitabilitas.

\section{TINJAUAN PUSTAKA}

\section{Agency Theory}

Agency theory menjelaskan hubungan antara agen (pihak manajemen suatu perusahaan) dengan principal (pemilik). Principal merupakan pihak yang memberikan amanat kepada agen untuk melakukan suatu jasa atas nama principal, sementara agen adalah pihak yang diberi mandat. Jadi dapat dikatakan bahwa agen bertindak sebagai pihak yang berkewenangan dalam mengambil keputusan, sedangkan principal ialah pihak yang mengevaluasi informasi.

Implementasi Agency theory dapat berupa kontrak kerja yang mengatur proporsi hak dan kewajiban masing-masing pihak dengan cara memaksimalkan utilitas. Dengan demikian diharapkan agen akan menggunakan cara-cara yang sesuai dengan 
kepentingan principal. Di pihak lain, principal memberikan insentif yang layak kepada agen, sehingga tercapai kontrak kerja yang optimal.

Menurut Scott dalam Arifin (2005), Agency theory adalah pendesainan kontrak yang tepat untuk menyelaraskan kepentingan principal dan agen dalam hal terjadinya konflik kepentingan. Dalam penelitian ini perusahaan bertindak sebagai principal, sementara auditor independen bertindak sebagai agen.

Konflik kepentingan dapat terjadi karena berbagai sebab, seperti : asimetri informasi. Asimetri informasi dimaknai sebagai ketidakseimbangan informasi akibat distribusi informasi yang tidak seimbang, antara agen dengan principal. Efek dari asimetri informasi dapat berupa moral hazard, yaitu permasalahan yang timbul, apabila agen tidak melaksanakan hal-hal dalam kontak kerja, atau terjadi adverse selection yaitu keadaan dimana principal tidak dapat mengetahui apakah keputusan yang diambil agen didasarkan atas informasi yang diperoleh, atau terjadi karena disebabkan suatu kelalaian dalam menjalankan tugas.

\section{Laporan Keuangan}

Laporan keuangan merupakan laporan yang menyediakan informasi yang terkait dengan posisi keuangan, kinerja, serta perubahan posisi keuangan perusahaan yang ditunjukkan untuk memenuhi kebutuhan bersama sebagian besar pengguna laporan (IAI, 2017).

Menurut PSAK No.1, laporan keuangan dapat dibagi menjadi:

1. Laporan Posisi Keuangan.

2. Laporan Laba Rugi dan Penghasilan Komprehensif lain

3. Laporan Arus Kas

4. Laporan Perubahan Ekuitas

5. Catatan atas Laporan Keuangan

Laporan Keuangan, dapat digunakan untuk memenuhi kebutuhan informasi yang berbeda, diantaranya :

1. Investor

2. Karyawan

3. Pemberi jaminan

4. Pemasok dan kreditur lain

5. Pelanggan

6. Pemerintah

7. Masyarakat

Ukuran perusahaan

Ukuran Perusahaan dapat diartikan sebagai suatu skala dimana dapat diklasifikasikan besar kecil suatu perusahaan, seperti : dinyatakan dalam total aktiva, nilai pasar saham, dan lain-lain. Keputusan Ketua Bapepam No. Kep.11/PM/1997 menyebutkan perusahaan kecil dan menengah berdasarkan aktiva (kekayaan), dalam penelitian ini variabel ukuran perusahaan diperoleh dengan persamaan berikut:

$$
\text { Ukuran Perusahaan }(\text { Size })=\text { Ln Total Asset }
$$

\section{Solvabilitas}

Menurut V. Wiratna Sujarweni (2017: 61) : solvabilitas merupakan yang digunakan untuk mengukur kemampuan perusahaan dalam memenuhi seluruh kewajibannya, baik dalam jangka pendek maupun jangka panjang.

Seberapa efektif perusahaan menggunakan sumberdaya yang dimiliki, seperti piutang, modal maupun aktiva. Total Debt to Equity Ratio (Rasio Hutang terhadap Ekuitas) merupakan perbandingan antara hutang-hutang dan ekuitas dalam pendanaan
Pengaruh

Ukuran

Perusahaan,

Solvabilitas, dan

Profitabilitas

terhadap Audit

Delay(Study

empiris pada

perusahaan

perbankan yang

terdaftar di

Bursa Efek

Indonesia) 
Pengaruh

Ukuran

Perusahaan,

Solvabilitas, dan

Profitabilitas

terhadap Audit

Delay(Study

empiris pada

perusahaan

perbankan yang

terdaftar di

Bursa Efek

Indonesia) perusahaan yang menunjukkan kemampuan modal sendiri/ perusahaan untuk memenuhi seluruh kewajibannya.

Dalam penelitian ini, rasio solvabilitas yang digunakan adalah rasio debt to equity, yaitu membagi total hutang dengan total ekuitas.

$$
\mathrm{DER}=\frac{\text { Total Utang }}{\text { Ekuitas Pemegang Saham }}
$$

\section{Profitabilitas}

Profitabilitas adalah kemampuan perusahaan dalam menghasilkan keuntungan pada tingkat penjualan, aset, dan modal saham tertentu. Profitabilitas dapat dijadikan sebagai salah satu indikator keberhasilan perusahaan dalam menghasilkan laba, semakin tinggi profitabilitas, maka semakin tinggi pula kemampuan perusahaan dalam menghasilkan laba bagi perusahaan (Siti Kholisah, 2013).

Tolak ukur tingkat profitabilitas menggunakan persamaan Return On Asset Ratio (ROA) sebagai berikut:

$$
\mathrm{ROA}=\frac{\text { Laba Bersih }}{\text { Total asset }}
$$

Audit

Menurut Sukrisno Agoes (2012: 4), auditing merupakan bentuk suatu pemeriksaan laporan keuangan yang dilakukan secara kritis dan sistematis, oleh pihak independen, beserta catatan-catatan pembukuan dan bukti-bukti pendukungnya, dengan tujuan dapat memberikan pendapat mengenai kewajaran laporan keuangan tersebut.

Terdapat beberapa jenis auditor, antara lain : auditor Independen (Akuntan Publik), Auditor Pemerintah, dan Auditor Internal (Internal Auditor). (Arens et all dalam Heru Setiawan, 2013).

Menurut Standar Pemeriksaan Akuntan Publik (SPAP, seksi 110) dalam Gita Carol (2017) menyatakan bahwa:

Tujuan Auditing atas laporan keuangan oleh auditor independen adalah untuk menyatakan pendapat tentang kewajaran, dalam semua hal yang material, posisi keuangan, hasil usaha, perubahan ekuitas, dan arus kas sesuai dengan prinsip akuntansi yang berlaku umum di Indonesia.

\section{Audit delay}

Menurut Fitri Ingga Saemargani (2015) audit delay merupakan jarak waktu antara tanggal laporan keuangan sampai tanggal saat auditor mengeluarkan laporan audit. Semakin lama auditor menyelesaikan lapporan audit maka audit delay semakin panjang. Dyer dan Mchugh dalam Kurniawan (2015) menggunakan tiga kriteria keterlambatan untuk melihat ketepatan waktu dalam penelitiannya, yaitu sebagai berikut:

1. Preliminary lag

2. Auditor's report lag

3. Total lag

\section{METODE PENELITIAN}

Penelitian ini menggunakan populasi yang berasal dari seluruh perusahaan perbankan yang terdaftar di Bursa Efek Indonesia. Sampel dalam penelitian ini adalah perusahaan perbankan yang terdaftar di Bursa Efek Indonesia tahun periode 2015 
sampai dengan tahun 2017 yang dipilih menggunakan metode purposive sampling, dengan kriteria pengambilan sampel, seperti :

1) Perusahaan terdaftar pada Bursa Efek Indonesia.

2) Perusahaan yang mempublikasikan laporan keuangan tahunan auditan berturutturut selama periode amatan.

3) Menerbitkan laporan keuangam dalam mata uang rupiah.

4) Perusahaan yang memiliki total aktiva lebih dari 500 miliyar.

Metode analisis yang digunakan dalam penelitian ini adalah analisis kuantitatif, yang meliputi : analisis statistik deskriptif, uji asumsi klasik, analisis regresi linier dan uji hipotesis baik parsial maupun simultan.

\section{HASIL DAN PEMBAHASAN}

\section{Analisis Statistik Deskriptif}

Dalam penelitian ini analisis statistik deskriptif diolah dengan menggunakan Statistic Product and Service Solution (SPSS). Pengujian statistik deskriptif penting dilakukan sebelum melakukan pengujian asumsi klasik dan pengujian hipotesis.

Statistik deskriptif adalah statistik yang digunakan untuk menganalisa data dengan cara mendeskripsikan atau menggambarkan data yang terkumpul. Statistik deskriptif dapat menjelaskan karakteristik memberikan penjelasan mengenai nilai minimum, nilai maksimum, nilai rata-rata (mean) dan nilai standard deviasi dari variabel-variabel independen dan variabel dependen. Berikut adalah analisis statistik deskriptif penelitian ini :

Tabel 1

Descriptive Statistics

\begin{tabular}{|l|r|r|r|r|r|}
\hline & $\mathrm{N}$ & Minimum & Maximum & Mean & $\begin{array}{c}\text { Std. } \\
\text { Deviation }\end{array}$ \\
\hline SIZE & 111 & 14,54 & 20,84 & 17,2198 & 1,77795 \\
DER & 111 &, 73 & 34,00 & 6,1807 & 3,73366 \\
ROA & 111 &,- 12 &, 11 &, 0060 &, 02503 \\
AUDIT_DELAY & 111 & 7 & 142 & 57,68 & 25,354 \\
Valid N (listwise) & 111 & & & & \\
\hline
\end{tabular}


Pengaruh

Ukuran

Perusahaan,

Solvabilitas, dan

Profitabilitas

terhadap Audit

Delay(Study

empiris pada

perusahaan

perbankan yang

terdaftar di

Bursa Efek

Indonesia)
Tabel 2

One-Sample Kolmogorov-Smirnov Test

\begin{tabular}{ll|r|}
\hline & & $\begin{array}{r}\text { Unstandardized } \\
\text { Residual }\end{array}$ \\
\hline $\mathrm{N}$ & Mean & 111 \\
Normal Parameters & a,b &, 0000000 \\
& Std. & 22,07680160 \\
Most Extreme & Deviation &, 074 \\
Differences & Absolute &, 055 \\
& Positive &,- 074 \\
Test Statistic & Negative &, 074 \\
Asymp. Sig. (2-tailed) & &, $170^{\mathrm{c}}$ \\
\hline a. Test distribution is Normal. & \\
b. Calculated from data. & \\
c. Lilliefors Significance Correction.
\end{tabular}

Dari hasil uji normalitas menunjukkan bahwa data terdistribusi secara normal. Karena nilai signifikansi dari uji normalitas adalah 0,170 artinya lebih besar dari 0,05 $(0,170>0,05)$. Dengan demikian dapat disimpulkan bahwa model penelitian ini memenuhi asumsi normalitas.

Tabel 3

Multikoleniaritas

\begin{tabular}{|c|c|c|c|}
\hline \multicolumn{4}{|c|}{ Coefficients $^{\mathbf{a}}$} \\
\hline \multirow{2}{*}{\multicolumn{2}{|c|}{ Model }} & \multicolumn{2}{|c|}{ Collinearity Statistics } \\
\hline & & Tolerance & VIF \\
\hline \multirow[t]{4}{*}{1} & (Constant) & & \\
\hline & SIZE & ,862 & 1,160 \\
\hline & DER & ,988 & 1,012 \\
\hline & ROA & ,872 & 1,147 \\
\hline
\end{tabular}

Sumber : Output SPSS

Berdasarkan hasil uji multikolinearitas diatas menunjukkan bahwa nilai VIF semua variabel $<10$ dan nilai tolerance $>0,1$, sehingga tidak terdapat gejala multikolinearitas. 
Uji Heteroskedastisitas

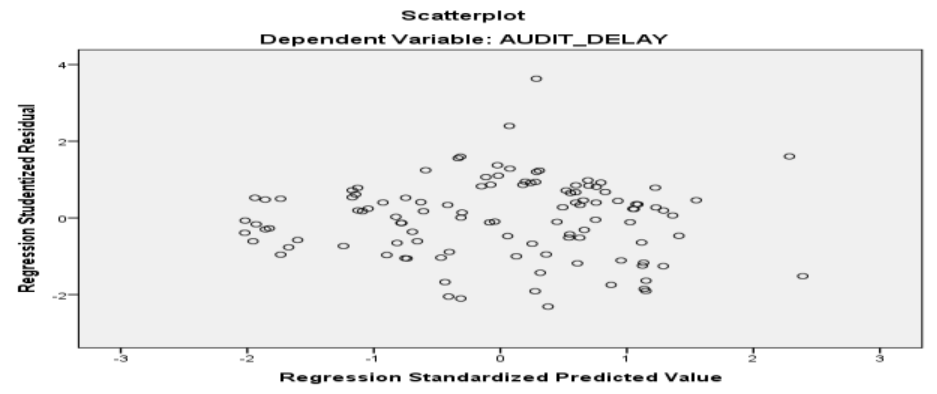

Gambar 1

Grafik Scatterplot

Berdasarkan grafik Scatterplot diatas, dapat dilihat bahwa tidak ada pola tertentu karena titik menyebar tidak beraturan. Dengan demikian dapat disimpulkan tidak terdapat gejala heteroskedastisitas pada model penelitian ini.

Uji Autokorelasi

Tabel 4

Model Summary ${ }^{b}$

\begin{tabular}{|l|c|r|r|r|r|}
\hline Model & $\mathrm{R}$ & $\begin{array}{c}\mathrm{R} \\
\text { Square }\end{array}$ & $\begin{array}{c}\text { Adjusted } \\
\text { R Square }\end{array}$ & $\begin{array}{c}\text { Std. Error of the } \\
\text { Estimate }\end{array}$ & Durbin-Watson \\
\hline 1 &, $492^{\mathrm{a}}$ &, 242 &, 221 & 22,384 & 2,003 \\
\hline
\end{tabular}

a. Predictors: (Constant), ROA, DER, SIZE

b. Dependent Variable: Audit_Delay

Berdasarkan hasil uji autokorelasi, nilai Durbin Watson (DW) menunjukkan nilai sebesar 2,003. Angka tersebut berada diantara DU dan 4-DU (1,6355 < 2,003 $<2,3645)$ karena DW berada diantara dua angka batasan autokorelasi, maka dapat disimpulkan bahwa tidak terjadi autokorelasi dalam penelitian ini.

Analisis Regresi Linear Berganda

Berdasarkan hasil pengolahan dara, diperoleh persamaan regresi linear berganda sebagai berikut:

$\mathrm{Y}=160,941-6,354 . \mathrm{X} 1+1,078 . \mathrm{X} 2-85.172 \cdot \mathrm{X} 3+e$

Keterangan :

$\mathrm{Y}=$ Audit delay

$\mathrm{X}_{1}=$ Ukuran Perusahaan (SIZE)

$\mathrm{X}_{2}=$ Solvabilitas (DER)

$\mathrm{X}_{3}=$ Profitabilitas (ROA)

$e=$ Standar Error 
Pengaruh Analisis regresi linear berganda

Ukuran

Perusahaan,

Solvabilitas, dan

Profitabilitas

terhadap Audit

Delay(Study

empiris pada

perusahaan

perbankan yang

terdaftar di

Bursa Efek

Indonesia)
Tabel 5

Coefficients $^{\mathbf{a}}$

\begin{tabular}{|c|c|c|c|c|c|c|c|}
\hline \multirow[b]{2}{*}{ Model } & \multicolumn{2}{|c|}{$\begin{array}{l}\text { Unstandardized } \\
\text { Coefficients }\end{array}$} & \multirow{2}{*}{$\begin{array}{c}\begin{array}{c}\text { Standardized } \\
\text { Coefficients }\end{array} \\
\text { Beta } \\
\end{array}$} & & \multirow[b]{2}{*}{ Sig. } & \multicolumn{2}{|c|}{$\begin{array}{c}\text { Collinearity } \\
\text { Statistics }\end{array}$} \\
\hline & $\mathrm{B}$ & $\begin{array}{l}\text { Std. } \\
\text { Error }\end{array}$ & & & & $\begin{array}{l}\text { Toler } \\
\text { ance }\end{array}$ & VIF \\
\hline 1 (Constant) & 160,941 & 22,085 & & 7,287 &, 000 & & \\
\hline SIZE & $-6,354$ & 1,293 &,- 446 & $-4,915$ & ,000 & ,862 & 1,160 \\
\hline DER & 1,078 & ,575 & , 159 & 1,875 & ,063 & ,988 & 1,012 \\
\hline ROA & $-85,172$ & 91,346 &,- 084 &,- 932 & ,353 & 872 & 1,147 \\
\hline
\end{tabular}

a. Dependent Variable: Audit_Delay

1. Nilai konstanta positif sebesar 160,941, artinya jika ukuran perusahaan (SIZE), Solvabilitas (DER), dan Profitabilitas (ROA) nilainya adalah 0 maka Audit delay menjadi sebesar 160,941 atau mengalami kenaikan sebesar 160,941. Jadi tanpa adanya variabel bebas/independen (SIZE, DER, dan ROA) perusahaan dapat mengalami audit delay selama 160,941 (160 hari).

2. Nilai koefisien regresi untuk variabel Ukuran Perusahaan (SIZE) memiliki nilai negatif sebesar -6,354. Artinya ukuran perusahaan berpengaruh negatif terhadap audit delay. Jadi semakin kecil ukuran perusahaan akan semakin panjang audit delay, demikian sebaliknya, semakin besar ukuran perusahaan akan semakin pendek Audit delay.

3. Nilai koefisien regresi untuk Solvabilitas positif sebesar 1,078 artinya apabila nilai solvabilitas naik sebesar satu satuan maka audit delay akan naik sebesar 1,078 apabila variabel lain dianggap konstan. Dengan kata lain, semakin tinggi solvabilitas akan semakin panjang audit delay.

4. Nilai koefisien regresi untuk variabel profitabilitas (ROA) memiliki nilai negatif sebesar -85,172, artinya profitabilitas berpengaruh negatif terhadap audit delay. Dengan demikian, jika variabel independen lain nilainya tetap sedang profitabilitas mengalami kenaikan satuan profitabilitas, maka audit delay akan turun sebesar 85,172 hari. Koefisien bernilai negatif artinya terjadi hubungan negatif antara profitabilitas dengan audit delay, jadi semakin besar keuntungan yang diperoleh perusahaan, akan semakin pendek terjadinya audit delay. Demikian sebaliknya, semakin kecil profitabilitas yang dimiliki perusahaan, akan mengakibatkan semakin panjangnya audit delay.

\section{Uji Parsial (Uji T)}


1. Ukuran Perusahaan (SIZE)

Hipotesis penelitian untuk variabel ukuran perusahaan adalah:

$\mathrm{H}_{1}$ : Ukuran perusahaan berpengaruh negatif dan signifikan terhadap audit delay.

Berdasarkan tabel hubungan antara ukuran perusahaan dengan audit delay, menunjukkan nilai signifikansi 0,000 , artinya lebih kecil dari nilai probabilitas $0,05(0,000<0,05)$. Dengan demikian hipotesis penelitian $\left(\mathrm{H}_{1}\right)$ diterima dan dapat disimpulkan bahwa ukuran perusahaan berpengaruh negatif dan signifikan terhadap audit delay. Tabel tersebut menunjukkan nilai t hitung sebesar $-4,915$ lebih kecil dari t tabel $-1,98238(-4,915<-1,98238)$. Hasil uji t menunjukkan bahwa ukuran perusahaan memiliki pengaruh negatif yang signifikan terhadap audit delay.

2. Solvabilitas

Hipotesis penelitian untuk variabel solvabilitas adalah:

$\mathrm{H}_{2}$ : DER berpengaruh positif dan signifikan terhadap audit delay

Berdasarkan tabel hubungan antara DER dengan audit delay, memperlihatkan nilai signifikansi 0,063 , artinya lebih besar dari nilai probabilitas $0,05(0,063>$ 0,05). Dengan demikian hipotesis penelitian $\left(\mathrm{H}_{2}\right)$ ditolak dan dapat disimpulkan bahwa DER tidak berpengaruh signifikan terhadap audit delay. Tabel tersebut menunjukkan nilai t hitung sebesar 1,875 artinya lebih kecil dari nilai t tabel sebesar $1,98238(1,875<1,98238)$. Hasil uji t menunjukkan bahwa DER tidak berpengaruh signifikan terhadap audit delay.

3. Pengaruh Profitabilitas (ROA) terhadap Audit delay

Tabel 6

Pengaruh

Ukuran

Perusahaan,

Solvabilitas, dan

Profitabilitas

terhadap Audit

Delay(Study

empiris pada

perusahaan

perbankan yang

terdaftar di

Bursa Efek

Indonesia)

Coefficients $^{\mathrm{a}}$

\begin{tabular}{|l|r|r|r|r|r|}
\hline \multirow{2}{*}{ Model } & \multicolumn{2}{|c|}{$\begin{array}{c}\text { Unstandardized } \\
\text { Coefficients }\end{array}$} & $\begin{array}{c}\text { Standardized } \\
\text { Coefficients }\end{array}$ & & \\
\cline { 2 - 4 } & \multicolumn{1}{|c|}{ B } & \multicolumn{1}{|c|}{$\begin{array}{c}\text { Std. } \\
\text { Error }\end{array}$} & \multicolumn{1}{|c|}{ Beta } & \multicolumn{1}{c|}{$\mathrm{t}$} & Sig. \\
\hline 1 (Constant) & 160,941 & 22,085 & & 7,287 &, 000 \\
SIZE & $-6,354$ & 1,293 &,- 446 & $-4,915$ &, 000 \\
DER & 1,078 &, 575 &, 159 & 1,875 &, 063 \\
ROA & $-85,172$ & 91,346 &,- 084 &,- 932 &, 353 \\
\hline
\end{tabular}

a. Dependent Variable: Audit_Delay

Hipotesis penelitian untuk variabel solvabilitas adalah :

$\mathrm{H}_{3}$ : ROA berpengaruh negatif dan signifikan terhadap audit delay. 
Berdasarkan tabel hubungan antara ROA dengan audit delay menunjukkan nilai signifikansi 0,353 , artinya lebih besar dari nilai probabilitas $0,05(0,353>0,05)$. Dengan demikian hipotesis penelitian $\left(\mathrm{H}_{3}\right)$ ditolak dan dapat disimpulkan bahwa ROA tidak berpengaruh signifikan terhadap audit delay. Tabel tersebut menunjukkan nilai $\mathrm{t}$ hitung sebesar $-0,932$ artinya lebih besar dari nilai $\mathrm{t}$ tabel sebesar -1,98238 (-0,932>-1,98238). Hasil uji t menunjukkan bahwa Profitabilitas tidak memiliki pengaruh yang signifikan terhadap audit delay.

\section{Uji F}

\section{ANOVA $^{\mathrm{a}}$}

\begin{tabular}{|c|c|c|c|c|c|}
\hline Model & $\begin{array}{c}\text { Sum of } \\
\text { Square } \\
\text { S }\end{array}$ & df & $\begin{array}{l}\text { Mean } \\
\text { Square }\end{array}$ & $\mathrm{F}$ & Sig. \\
\hline 1 Regre & $\begin{array}{r}17097, \\
505\end{array}$ & 3 & $\begin{array}{r}5699,1 \\
08\end{array}$ & $\begin{array}{r}11,3 \\
75\end{array}$ & $\begin{array}{r}, 000 \\
\mathrm{~b}\end{array}$ \\
\hline & & & & & \\
\hline $\begin{array}{l}\text { Resid } \\
\text { ual }\end{array}$ & $\begin{array}{r}53612, \\
369\end{array}$ & 107 & $\begin{array}{r}501,05 \\
0\end{array}$ & & \\
\hline Total & $\begin{array}{r}70709, \\
964\end{array}$ & 110 & & & \\
\hline
\end{tabular}

a. Dependent Variable: Audit_Delay

b. Predictors: (Constant), ROA, DER, SIZE

Pengaruh
Ukuran
Perusahaan,
Solvabilitas, dan
Profitabilitas
terhadap Audit
Delay(Study
empiris pada
perusahaan
perbankan yang
terdaftar di
Bursa Efek
Indonesia)

Berdasarkan analisis uji $\mathrm{F}$ pada tabel diatas, diketahui bahwa nilai signifikansi untuk pengaruh ukuran perusahaan, DER dan ROA secara simultan terhadap audit delay adalah $0,000<0,05$. Nilai $\mathrm{F}$ hitung $11,375>2,69$, dapat disimpulkan bahwa $\mathrm{H}_{4}$ diterima, artinya terdapat pengaruh antara ukuran perusahaan $\left(\mathrm{X}_{1}\right)$, DER $\left(\mathrm{X}_{2}\right)$, dan ROA $\left(\mathrm{X}_{3}\right)$ secara simultan terhadap Audit delay $(\mathrm{Y})$.

\section{Uji Koefisien Determinasi}

\begin{tabular}{|l|c|r|c|c|c|}
\hline \multicolumn{7}{|c|}{ Model Summary $^{\mathbf{b}}$} \\
Model & $\mathrm{R}$ & R Square & $\begin{array}{c}\text { Adjusted R } \\
\text { Square }\end{array}$ & $\begin{array}{l}\text { Std. Error of } \\
\text { the Estimate }\end{array}$ & $\begin{array}{c}\text { Durbin- } \\
\text { Watson }\end{array}$ \\
\hline 1 &, $492^{\mathrm{a}}$ &, 242 &, 221 & 22,384 & 2,003 \\
\hline
\end{tabular}

a. Predictors: (Constant), ROA, DER, SIZE

b. Dependent Variable: AUDIT_DELAY

Berdasarkan tabel diatas, diperoleh nilai koefisien determinasi sebesar 0,242 (24,2\%), artinya kemampuan variabel independen (Ukuran Perusahaan, DER, dan ROA) dalam menerangkan variabel dependen (Audit delay) sebesar 24,2\%, sedang sisanya 75,8\% (100\%-24,2\%) ditentukan oleh faktor lain yang tidak diteliti dalam penelitian ini.

Pengaruh Ukuran Perusahaan Terhadap Audit delay

Ukuran perusahaan mempunyai pengaruh signifikan negatif terhadap audit delay, artinya semakin besar total asset yang dimiliki suatu perusahaan maka akan semakin kecil audit delay. Hal ini terjadi karena perusahaan besar mempunyai sistem pengendalian internal yang baik, sehingga dapat mengurangi tingkat kesalahan dalam penyajian laporan keuangan perusahaan. Hal ini akan memudahkan auditor dalam melakukan audit terhadap laporan keuangan. Perusahaan besar mempunyai sumber daya 
keuangan untuk membayar audit fee, guna mendapatkan pelayanan audit yang lebih cepat, perusahaan cenderung mendapat tekanan yang tinggi dari pihak eksternal terhadap kinerja keuangan perusahaan, sehingga manajemen akan berusaha untuk mempublikasikan laporan audit keuangannya tepat waktu.

Hasil penelitian ini didukung oleh hasil penelitian Andi Kartika (2009), Heru Setiawan (2013), Sistya Rahmawati (2008), Malinda (2015), Nurahman Apriyana (2017), yang menyatakan bahwa ukuran perusahaan memiliki pengaruh yang signifikan terhadap audit delay. Karena Manajemen dengan skala besar cenderung diberikan insentif untuk mempercepat penerbitan laporan keuangan audit, hal ini disebabkan karena perusahaan berskala besar dimonitor secara ketat oleh investor, pengawas permodalan dan pemerintah sehingga cenderung menghadapi tekanan eksternal yang lebih tinggi untuk mengumumkan laporan keuangan auditnya lebih awal.

Hasil penelitian ini tidak didukung dengn hasil penelitian Dewi Lestari (2010), Siti Aliyah Nur Kholisah (2013), Anak Agung Gede Wiryakriyana dan Ni Luh Sari Widhiyani (2017), I Putu Yoga Darmawan dan Ni Luh Sari Widhiyani (2017) yang menyatakan bahwa semua perusahaan yang terdaftar di Bursa Efek Indonesia diawasi oleh investor, pengawas permodalan, pemerintah serta masyarakat. Dengan demikian perusahaan dengan total aset besar maupun kecil mempunyai kemungkinan yang sama dalam mengahadapi tekanan atas penyampaian laporan keuangan.

\section{Pengaruh Solvabilitas terhadap Audit delay}

Solvabilitas memiliki pengaruh positif dan tidak signifikan terhadap audit delay. Kemampuan perusahaan dalam membayarkan semua hutang-hutangnya ternyata tidak berpengaruh terhadap Audit delay. Hal tersebut disebabkan karena standar pekerjaan auditor yang telah diatur dalam SPAP menyatakan bahwa pelaksanaan prosedur audit perusahaan baik yang memiliki total hutang besar dengan jumlah debt holder yang banyak atau perusahaan dengan hutang yang kecil dan jumlah debt holder sedikit tidak akan mempengaruhhi proses penyelesaian audit laporan keuangan, karena auditor yang ditunjuk telah menyediakan waktu sesuai dengan kebutuhan untuk menyelesaikan proses audit.

Peraturan Otoritas Jasa Keuangan dalam undang-undang nomor 29/POJK.04/2016 mengenai sanksi yang akan diterima emiten atas keterlambatan penyampaian laporan keuangan audit ke BEI, sesuai pasal 19 point 1 dimana sanksi yang diberlakukan adalah : (1) peringatan tertulis, (2) denda, (3) pembatasan kegiatan usaha, (4) pembekuan kegiatan usaha, (5) pencabutan izin usaha, (6) pembatalan persetujuan dan, (7) pembatalan pendaftaran, dan juga adanya dampak-dampak negatif lain atas keterlambatan publikasi laporan keuangan, menuntut seluruh emiten baik perusahaan dengan tingkat solvabilitas yang rendah maupun tinggi untuk menyampaikan laporan keuangan dengan tepat waktu. Oleh karena itu auditor harus bekerja secara tepat, baik pada saat pemeriksaan (auditing) dan saat penyelesaiannya.

Hubungan audit delay dengan tingkat solvabilitas perusahaan di mata auditor sebagai pemeriksa laporan keuangan adalah : perusahaan memiliki rasio solvabilitas yang baik atau tidak, auditor harus tetap melaksanakan audit dengan cermat dan seksama, untuk kemudian menyatakan simpul dalam bentuk pendapat atas hasil auditnya. Dari sudut pandang auditor baik perusahaan yang memiliki solvabilitas tinggi maupun rendah, tidak mempengaruhi panjang atau pendeknya waktu audit (audit delay), karena yang menjadi fokus auditor adalah menyelesaikan audit melalui laporan auditor yang berisi opini, sesuai dengan kondisi sebenarnya dan berdasarkan audit finding yang diperoleh.

Hasil penelitian ini sesuai dengan hasil penelitian Fitria Ingga Saemargani (2015), Rizki Hadiyanti (2015), Ani Yulianti (2011) yang menyatakan bahwa solvabilitas perusahaan tidak mempunyai pengaruh yang signifikan terhadap audit 
Pengaruh

Ukuran

Perusahaan,

Solvabilitas, dan

Profitabilitas

terhadap Audit

Delay(Study

empiris pada

perusahaan

perbankan yang

terdaftar di

Bursa Efek

Indonesia) delay. Hasil penelitian ini tidak didukung oleh hasil penelitian Nurrahman Apriyana (2017), Andi Kartika (2011), dan Heru Setiawan (2013) yang mengatakan bahwa solvabilitas berpengaruh terhadap audit delay. Hal ini disebabkan karena tingkat besar kecilnya hutang yang dimiliki perusahaan menyebabkan pemeriksaan dan pelaporan terhadap utang perusahaan akan semakin lama, sehingga memperlambat proses pelaporan audit oleh auditor.

\section{Pengaruh Profitabilitas terhadap audit delay}

Kemampuan perusahaan dalam mendapatkan laba tidak berpengaruh terhadap audit delay. Profitabilitas yang tercermin pada Return On Asset (ROA) tidak memiliki pengaruh signifikan terhadap audit delay. Hal ini disebabkan karena tidak adanya perbedaan proses audit pada perusahaan dengan tingkat kemampuan laba yang rendah maupun tinggi. Perusahaan dengan profitabilitas rendah maupun tinggi, cenderung untuk menyelesaikan audit dengan tepat waktu, mengingatkan adanya sanksi yang akan diterima emiten atas keterlambatan penyampaian laporan keuangan hasil audit ke BEI. Dampak negatif atas keterlambatan tersebut, adalah menurunnya harga saham, serta merusak citra perusahaan di mata pihak-pihak yang berkepentingan dengan laporan keuangan audit.

Selain itu, auditor sebagai pemeriksa laporan keuangan memiliki etika profesi yang diatur pada SPAP yang berbunyi :"dalam pelaksanaan audit dan penyusunan laporan, auditor wajib menggunakan kemahiran profesinya dengan cermat dan seksama". Pernyataan ini secara jelas menuntut auditor untuk bekerja secara profesional. Sama halnya dengan solvabilitas, hubungan antara audit delay dengan tingkat profitabilitas perusahaan dimana auditor sebagai pemeriksa laporan keuangan adalah : bahwa baik perusahaan yang memiliki rasio profitabilitas yang tinggi maupun rendah, auditor harus tetap melaksanakan audit dengan cermat dan seksama, kemudian menyimpulkan hasil audit. Dari sudut pandang auditor baik perusahaan yang memiliki profitabilitas tinggi maupun rendah, tidak mempengaruhi waktu audit (audit delay) suatu perusahaan, karena yang menjadi fokus auditor adalah menyelesaikan audit dengan hasil opini yang dinyatakan sesuai dengan kondisi sebenarnya.

Hasil penelitian ini didukung penelitian Sistya Rachmawati (2008) Andi Kartika (2009) dan Nurahman Apriyana (2017) yang menemukan bukti empiris bahwa ROA tidak memiliki pengaruh signifikan terhadap audit delay. Namun hasil penelitian ini tidak didukung hasil penelitian oleh Raja Adzrin Raja Ahmad dan Khairul Anuar Bin Kamarudin (2003), Heru Setiawan (2013) dan Siti Aliyah Nur Kholisah (2013), Fitria Ingga Saemargani (2015), Fauziah Althaf Amani (2016) yang menyatakan perusahaan yangg memperoleh kabar baik cenderung akan lebih tepat waktu dalam penyampaian laporan keuangan dibandingkan dengan perusahaan yang memperoleh kabar buruk, dimana hasil penelitian menjelaskan bahwa profitabilitas memiliki pengaruh negatif dan signifikan terhadap audit delay. Hal ini menunjukkan bahwa semakin tinggi profitabilitas maka semakin pendek audit delay. Perbedaan hasil penelitian ini dapat disebabkan oleh pemilihan sampel dan periode penelitian yang berbeda.

\section{Pengaruh Ukuran Perusahaan, Solvabilitas, dan Profitabilitas terhadap Audit delay}

Secara bersamaan ukuran perusahaan, solvabilitas dan profitabilitas berpengaruh terhadap audit delay. Jumlah laba bersih sering dibandingkan dengan ukuran kegiatan atau kondisi keuangan lainnya seperti penjualan, aktiva, ekuitas pemegang saham untuk menilai kinerja sebagai suatu persentase dari beberapa tingkat aktivitas atau investasi. Dengan demikian perusahaan yang memiliki tingkat profitabilitas yang tinggi berarti perusahaan telah menggunakan asset-assetnya secara efesien, sehingga menghasilkan laba yang tinggi bagi perusahaan maupun pemegang saham. Tingginya laba atau profitabilitas suatu perusahaan mengindikasikan bahwa perusahaan tersebut mengalami 
keuntungan dan dengan laba yang tinggi berarti perusahaan memiliki solvabilitas yang rendah karena perusahaan dapat melunasi hutang jangka pendek maupun jangka panjang. Hal ini mencerminkan bahwa perusahaan dalam keadaan sehat karena sumber pendanaannya dibiayai oleh keuangan sendiri bukan dibiayai oleh kreditor (pemberi hutang). Tingginya profitabilitas dan rendahnya solvabilitas suatu perusahaan dapat mengindikasikan bahwa suatu perusahaan dapat dikategorikan perusahaan besar, sedang ataupun kecil. Perusahaan dengan kategori perusahaan besar mempunyai manajemen yang besar, sehingga mempunyai sistem pengendalian internal yang baik, hal itu dapat mengurangi tingkat kesalahan dalam penyajian laporan keuangan perusahaan, sehingga memudahkan auditor dalam melakukan audit terhadap laporan keuangan, manajemen dengan skala besar cenderung diberikan insentif untuk mempercepat penerbitan laporan keuangan audit, agar mengumumkan laporan keuangan audit lebih awal.

Dengan demikian dapat disimpulkan bahwa variabel independen Profitabilitas, Solvabilitas, dan Ukuran Perusahaan memiliki pengaruh terhadap audit delay, hal ini disebabkan karena semua kandungan informasi dalam Ukuran Perusahaan, Solvabilitas, dan Profitabilitas mempunyai peranan penting dalam menentukan panjang pendeknya audit delay perusahaan.

\section{SIMPULAN DAN SARAN}

\section{Simpulan}

Berdasarkan hasil pengolahan data, maka dapat disimpulkan bahwa :

1. Ukuran perusahaan memiliki pengaruh negatif terhadap Audit Delay.

2. Solvabilitas tidak memiliki pengaruh signifikan terhadap audit delay.

3. Profitabilitas tidak memiliki pengaruh signifikan terhadap audit delay.

4. Profitabilitas, Solvabilitas, dan Ukuran Perusahaan, secara simultan atau bersama-sama memiliki pengaruh yang siginifikan terhadap audit delay.

\section{Saran}

Penelitian ini memiliki keterbatasan-keterbatasan, karenanya saran yang dapat diberikan adalah :

1. Bagi peneliti selanjutnya diharapkan menggunakan keseluruhan jenis perusahaan yang terdaftar di BEI, bukan hanya sebatas perusahaan perbankan.

2. Menambahkan dan menggunakan variabel independen yang diduga memiliki pengaruh terhadap audit delay seperti jenis industri, ukuran KAP, opini auditor, laba rugi, tingkat leverage, komite audit dan lain sebagainya.

3. Memperpanjang periode penelitian sehingga dapat menggambarkan kecenderungan akan kondisi yang sesungguhnya.

\section{DAFTAR PUSTAKA}

Agoes, Sukrisno, 2012. Auditing Petunjuk Pemeriksaan Akuntan oleh Akuntan Publik. Jakarta: Edisi ke empat: Salemba Empat.

Carrol, Gita. 2017. Pengaruh Profitabilitas dan Ukuran Perusahaan terhadap Audit Delay (Studi Empiris Perusahaan Manufaktur yang Terdaftar di Bursa Efek Indonesia ). Skripsi. Sekolah Tinggi Ilmu Ekonomi Kesatuan.

Ikatan Akuntan Indonesia. 2012. Standar Akuntansi Keuangan. Jakarta: Salemba Empat.

Lukviarman, Niki. Corporate Governance (2016:38)

Otoritas Jasa Keuangan Republik Indonesia Peraturan Otoritas Jasa Keuangan No. 29/POJK.04/2016 Tentang Laporan Tahunan Emiten Atau Perusahaan Publik. 
PSAK No 01 (2017: 9)

Setiawan, Heru. 2013. Pengaruh Ukuran Perusahaan, Reputasi Auditor, Opini Audit, Profitabilitas, dan Solvabilitas Terhadap Audit Delay. Universitas Islam Syarif Hidayatullah Jakarta.

Saemargani, Fitria Ingga. 2015. Pengaruh Ukuran Perusahaan, Umur Perusahaan, Profitabilitas, Solvabilitas, Ukuran KAP, dan Opini Auditor terhadap Audit Delay. Jurnal Ilmu dan Riset Akuntansi Vol IV No.2 16: 1-15. Universitas Negeri Yogyakarta.

Wiryakriyai, Anak Agung Gede dan Ni Luh Sari Widhiyani. 2017. Pengaruh Ukuran Perusahaan, Leverage, Auditor Switching, dan Sistem Pengendalian Internal Pada Audit Delay. Jurnal Ilmu dan Riset Akuntansi Vol. 19. 1. April (2017): 771-798.

Yulianti, Ani. 2011. Faktor-Faktor yang Berpengaruh Terhadap Audit Delay (Studi Empiris Pada Perusahaan-perusahaan Manufaktur Yang Terdaftar di Bursa Efek Indonesia Tahun 2007-2008).

Bursa Efek Indonesia. Website: http://www.idx.co.id ( diakses tanggal 9 mei 2018)

Hasibuan, D. and Auliya, M. 2019. The Effects of Characteristics of the Board of Commissioners and Audit Committee on the Level of Risk Disclosure in Financial Sector Service Companies in the Banking Sector Listed on the Indonesia Stock Exchange in the Period 2015-2017. Jurnal Riset. 1, 2 (Sep. 2019), 079 - 089. 